\title{
Article
}

\section{Serbian Twin Registry}

\author{
Snežana Smederevac ${ }^{1}$, Dušanka Mitrović ${ }^{1}$, Selka Sadiković ${ }^{1}$, Ilija Milovanović ${ }^{1}$, Bojan Branovački ${ }^{1}$, Bojana M. Dinić ${ }^{1}$, \\ Željka Nikolašević ${ }^{2}$ Jasmina Kodžopeljić ${ }^{1}$, Vojislava Bugarski Ignjatović ${ }^{2}$, Marija Semnic ${ }^{3}$, Tijana Vujanić Stankov ${ }^{3}$, \\ Nataša Vučinić ${ }^{4}$, Milan Oljača ${ }^{1}$, Dejan Pajić ${ }^{1}$, Aleksandra Stojadinović ${ }^{5}$, Tatjana Krstić ${ }^{2}$ and Aleksandra Milutinović ${ }^{6}$ \\ ${ }^{1}$ Department of Psychology, Faculty of Philosophy, University of Novi Sad, Novi Sad, Serbia, ${ }^{2}$ Department of Psychology, Faculty of Medicine, University of \\ Novi Sad, Novi Sad, Serbia, ${ }^{3}$ Department of Neurology, Faculty of Medicine, University of Novi Sad, Novi Sad, Serbia, ${ }^{4}$ Department of Pharmacy, Faculty \\ of Medicine, University of Novi Sad, Novi Sad, Serbia, ${ }^{5}$ Department of Pediatrics, Faculty of Medicine, University of Novi Sad, Novi Sad, Serbia and \\ ${ }^{6}$ Faculty of Medicine, University of Novi Sad, Novi Sad, Serbia
}

\begin{abstract}
The first twin study in Serbia began in 2011 as a part of the research project, 'Psychological Foundations of Mental Health: Hereditary and Environmental Factors'. At the same time, the research team from the Faculty of Philosophy and Faculty of Medicine in Novi Sad established the first Serbian twin registry. The registry is intended primarily for the purpose of the research in behavioral genetics, as well as potential future studies in human genetics. It includes information on 1658 volunteers, including twin-pairs, their parent and siblings. The behavioral genetic study of adult twins has been focused on the hereditary and environmental sources of variance of different psychological characteristics, such as personality traits, cognitive abilities, executive functions and aggression, as well as some anthropometric measures and aspects of mental and physical health. Certain molecular genetic analyses have also been performed. The research team is currently starting the longitudinal twin study of children, which will be focused on different indicators of emotional, cognitive and physical development.
\end{abstract}

Keywords: Twin study; personality; cognitive abilities; health; life events; developmental characteristics

(Received 21 October 2019; accepted 24 October 2019; First Published online 26 December 2019)

\section{Background of the First Twin Study in Serbia}

The Serbian Twin Registry (STR) was created in 2011 as a part of the research project 'Psychological Foundations of Mental Health: Hereditary and Environmental Factors', granted by the Ministry of Education, Science and Technological Development of the Republic of Serbia. Researchers participating in the study are from the Department of Psychology at the Faculty of Philosophy and from the Faculty of Medicine at the University of Novi Sad. This interdisciplinary team is trying to answer some important questions of behavioral genetics. The registry is intended primarily for the purpose of the research in behavioral genetics, as well as studies in molecular human genetics. In 2014, the research team established the Center for Behavioral Genetics (CBG), as an organizational unit of the Faculty of Philosophy in Novi Sad, in which biometric and molecular genetic analyses are conducted, based on the data collected through the STR. The STR and the CBG are the first and only institutions of this type in Serbia.

Author for correspondence: Snežana Smederevac, Email: snezana.smederevac@uns.ac.rs Cite this article: Smederevac S, Mitrović D, Sadiković S, Milovanović I, Branovački B, Dinić BM, Nikolašević Ž, Kodžopeljić J, Bugarski Ignjatović V, Semnic M, Vujanić Stankov T, Vučinić N, Oljača M, Pajić D, Stojadinović A, Krstić T, and Milutinović A. (2019) Serbian Twin Registry. Twin Research and Human Genetics 22: 660-666, https://doi.org/10.1017/thg.2019.114

\section{Recruitment of the Twins and Online Platform for Data Collection}

The official website of the STR is available at http://www.blizanci.rs/. The website provides information on the importance of twin research for science, scientific results of previous twin studies, facts about the project, research team and the CBG. Twins and their parents who are willing to take part in the research can apply for participation through the publicly available application form on the STR website. Invitations for participation are being sent via media, press, newspapers, social networks, promotional posters and leaflets, and through various public campaigns. After the participants submit the application to the STR, we are reaching them through an email or telephone contact to take part in the study. Additionally, a custom web application was developed in order to distribute questionnaires online and collect data directly into the database. Data collection platform is available only to registered twin-pairs having unique security codes, in order to protect potentially sensitive personal information. Through the web application, twin-pairs can complete all the test material, which significantly facilitates and accelerates the process of data collection.

\section{Ethical Issues}

All procedures for the twin study were approved by the Ethical Committee of the Faculty of Philosophy, University of Novi Sad, Serbia, which is the Second Instance Commission of the Ethical Committee of the Serbian Psychological Society. The approval 
certificate can be found at the following link: http://psihologija.ff. uns.ac.rs/etika/?odobreno=20111020000004_e1b8

Before participation in the study, all twins were informed about the main purpose of the study and signed informed consent forms. Since the Competitive Reaction Time Task (CRTT) includes deception about the real purpose of the examination, all participants were debriefed immediately after they finished this task. Namely, in this procedure, participants were led to believe that they compete with each other in reaction time, but actually there was no real competition.

\section{Sample}

The STR contains information on 1658 volunteers, including twins, their parents and siblings (Figure 1). A total of 722 registered twin-pairs includes 295 twin-pairs who were already registered and tested, 327 youth and 100 adult twin-pairs who were registered and scheduled to be tested in the next stage of the study. Additionally, the STR includes 214 family members of the twins. Following their participation in the research, twins were asked to invite their family members to join this research and complete several self-report questionnaires (Table 1).

Table 2 presents participants of the STR who finished testing as of 2019. We examined 295 twin-pairs who were reared together. Twin participants were aged 16-60 years old with an average age of $24.49(S D=7.59)$. Among the pairs, there were 180 monozygotic (MZ) twins and 93 dizygotic (DZ) twins. For the remaining 22 twinpairs, zygosity has not yet been determined and is currently being analyzed. In total, there were 263 male and 541 female participants, including twins and their family members. Among the DZ twinpairs, there were 47 opposite-sex pairs and 46 same-sex gender pairs. Family members of 96 twin-pairs participated in the study, of whom there were 76 fathers, 86 mothers and 52 siblings ( 20 brothers and 32 sisters).

\section{Zygosity Determination}

Zygosity was determined by DNA analysis of buccal swabs and is still being determined for new samples. The research was performed according to the Declaration of Helsinki. One part of the DNA samples was analyzed at the Institute of Forensic Medicine Novi Sad, and the other part at John Jay College of Criminal Justice in New York. For new samples, analyses are still ongoing at John Jay College of Criminal Justice in New York, NY. DNA is tested using short tandem repeat megaplex kits, either Investigator 24plex GO! (Qiagen, Valencia, CA, USA) or GlobalFiler kit (Applied Biosystems, Thermofisher Scientific, Waltham, MA, USA) according to the manufacturer's recommendations. Both kits detect 21 autosomal short tandem repeats. A completely concordant pair with these short tandem repeats is interpreted as a MZ twin-pair and all the other pairs are designated as DZ.

For a small part of sample (1\%), the zygosity was determined using the Twins Physical Resemblance Questionnaire (Oniszczenko et al., 1993). This questionnaire includes a series of questions about similarities and dissimilarities between two twins, within twin-pairs (e.g., eye color, body weight and body height). These items have been shown to be valid indicators of zygosity, with zygosity determination being accurate around 95\% (e.g., Čolović et al., 2019; Reed et al., 2005).

\section{Measures}

The behavioral genetic study of adult twins has been focused on the hereditary and environmental sources of variance of different psychological characteristics, such as personality traits, cognitive
Table 1. List of measures

\begin{tabular}{|c|c|c|c|}
\hline Assessment & $\begin{array}{l}\text { Adult } \\
\text { twins }\end{array}$ & Parents & Siblings \\
\hline \multicolumn{4}{|l|}{ Personality } \\
\hline NEO PI-R (Costa \& McCrae, 1992) & + & + & + \\
\hline $\begin{array}{l}\text { NEO-FFI (Costa \& McCrae, 1992; } \\
\text { Costa \& McCrae, 2019) }\end{array}$ & + & + & + \\
\hline RSQ (Smederevac et al., 2014) & + & + & + \\
\hline SSS V (Zuckerman, 1994) & + & + & + \\
\hline AQ (Buss \& Perry, 1992) & + & + & + \\
\hline CRTT (Taylor, 1967) & + & & \\
\hline \multicolumn{4}{|l|}{ Cognition } \\
\hline APM (Raven et al., 1998) & + & & \\
\hline WCST (Heaton et al., 1993) & + & & \\
\hline TMT (Reitan, 1955) & + & & \\
\hline $\begin{array}{l}\text { VFT (Goodglass \& Kaplan, 1983; } \\
\text { Lezak, 1995) }\end{array}$ & + & & \\
\hline \multicolumn{4}{|l|}{ Family environment } \\
\hline BEQ (Riemann \& Wagner, 2000) & + & & \\
\hline ASRQ (Stocker et al., 1995) & + & & \\
\hline \multicolumn{4}{|l|}{ Mental health } \\
\hline PDSQ (Zimmerman, 2002) & + & & \\
\hline SWLS (Diener et al., 1985) & + & + & + \\
\hline $\begin{array}{l}\text { Life events list (Plomin et al., 1990; } \\
\text { Saudino et al., 1997) }\end{array}$ & + & & \\
\hline Medical examination & + & & \\
\hline Anthropometrical measures & + & & \\
\hline DNA sampling & + & & \\
\hline \multicolumn{4}{|l|}{ Genes } \\
\hline COMT & + & & \\
\hline DRD2 & + & & \\
\hline BDNF & + & & \\
\hline HTR1A & + & & \\
\hline $\mathrm{TPH} 2$ & + & & \\
\hline
\end{tabular}

NEO PI-R = NEO personality inventory; NEO-FFI = NEO five-factor inventory; $\mathrm{RSQ}=$ reinforcement sensitivity questionnaire; SSS V = sensation seeking scale; $\mathrm{AQ}=$ aggression questionnaire; $\mathrm{CRTT}=$ competitive reaction time task; $\mathrm{APM}=$ advanced progressive matrices; WCST $=$ Wisconsin Card sorting test; $T M T=$ trail making test; $\mathrm{VFT}=$ verbal fluency test; $\mathrm{BEQ}=$ block environmental questionnaire; $\mathrm{ASRQ}=$ adult sibling relationship questionnaire; $\mathrm{PDSQ}=$ psychiatric diagnostic screening questionnaire; SWLS $=$ satisfaction with life scale; COMT $=$ Catechol-O-methylTransferase; $\mathrm{DRD} 2$ = dopamine $\mathrm{D} 2$ receptor; $\mathrm{BDNF}=$ brain-derived neurotrophic factor; HTR1A = hydroxytryptamine receptor $1 \mathrm{~A} ; \mathrm{TPH} 2=$ tryptophan hydroxylase 2.

abilities, executive functions and aggression, as well as some anthropometric measures and aspects of mental and physical health.

Therefore, the measures are divided into several primary areas: personality assessment, assessment of cognitive abilities, assessment of executive functions, assessment of family environment, life events, aspects of mental health, assessment of laboratory-induced aggression, medical examination and DNA sampling.

\section{Personality Measures}

Revised NEO Personality Inventory (NEO PI-R; Costa \& McCrae, 1992) and NEO Five-Factor Inventory (NEO-FFI; Costa \& McCrae, 
Table 2. Participants $(N=804)$ who completed tests in the Serbian Twin Registry as of 2019

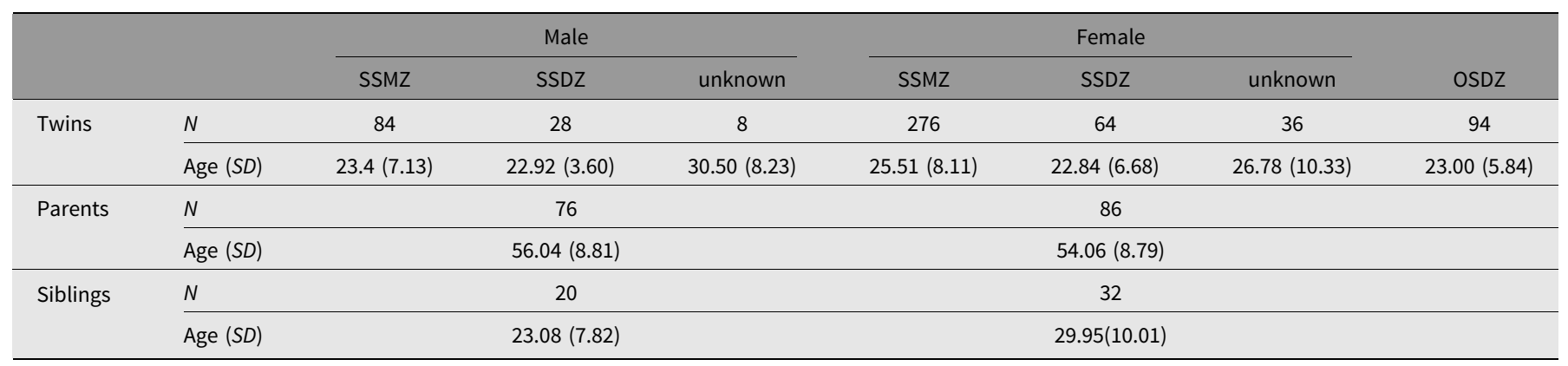

$N=$ number of individuals (not pairs); SS = same-sex; MZ = monozygotic twins; DZ = dizygotic twins; unknown = zygosity unknown; Age = age in years; OSDZ = opposite-sex dizygotic twins.

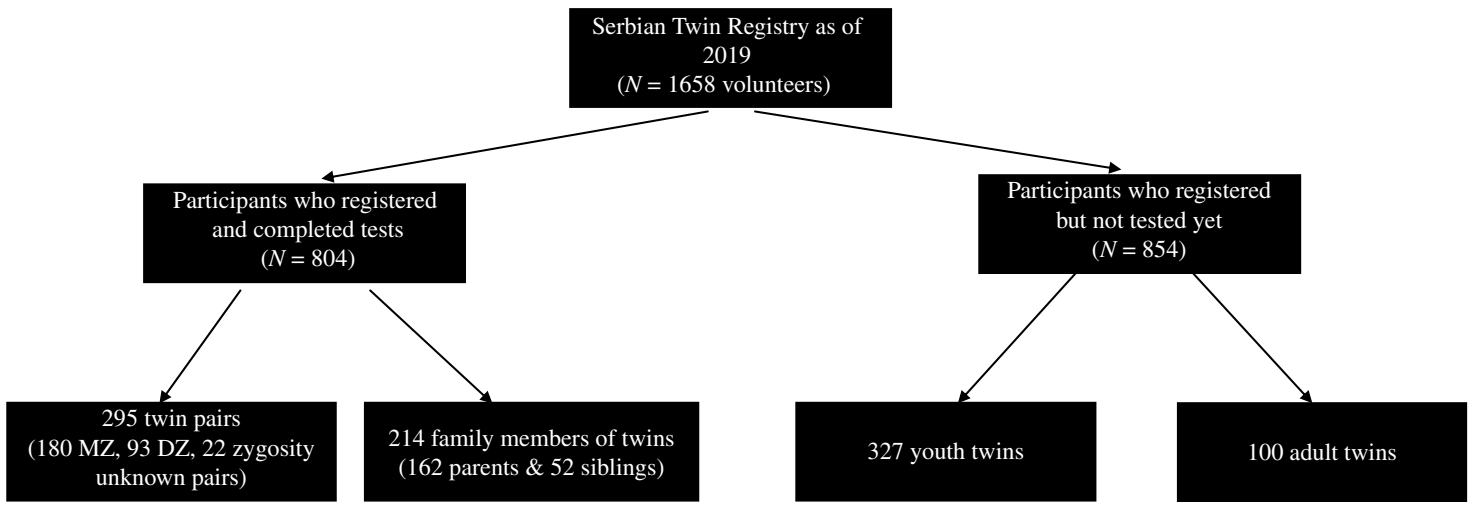

Fig. 1. The participants of the Serbian Twin Registry as of 2019.

1992; Costa \& McCrae, 2019). The NEO PI-R is designed to assess Big Five personality traits - Openness to Experience $(\mathrm{O})$, Conscientiousness (C), Extraversion (E), Agreeableness (A), and Neuroticism (N) - with 240 items, while the NEO-FFI is a short version of the NEO PI-R, comprising 60 items.

Reinforcement Sensitivity Questionnaire (Smederevac et al., 2014) is based on the revised Reinforcement Sensitivity Theory (rRST; Gray \& McNaughton, 2000) and contains 29 items with a 4-point Likert scale distributed in 5 scales: Behavioral inhibition system (BIS), Behavioral activation system (BAS); Fight, and Flight and Freeze.

Sensation Seeking Scale (Zuckerman, 1994) consists of 40 items with a 5-point Likert scale, measuring 4 components of sensation seeking: Thrill and Adventure Seeking, Experience Seeking, Disinhibition and Boredom Susceptibility.

Aggression Questionnaire (Buss \& Perry, 1992; for Serbian adaptation see Dinić \& Janičić, 2012) consists of 29 items with a 5-point Likert scale, measuring 4 components of aggressiveness: Physical and Verbal Aggression, Anger, and Hostility.

CRTT (also known as the Taylor Aggression Paradigm, Taylor, 1967; for details see Warburton \& Bushman, 2019) has been used for aggression induction. In this procedure, twins are led to believe they are competing with each other in the reaction time tasks. Before each task, each twin has an opportunity to set the 'punishment' for his/her twin-pair. The punishment comprised a settled intensity and duration of an aversive noise. If one twin lost, he/ she would receive the punishment determined by the winning twin. There were 4 blocks in the procedure (each contained 10 tasks), with the first block designed as a practice in which twins only gave the punishment and did not receive it if they lost. In the 2-4 blocks, twins received predetermined punishments that increased during the procedure. In each block, it was settled that participants randomly won in $50 \%$ of the tasks. The aggression measures were settled intensity and duration of the punishments by twins.

\section{Cognition Measures}

Advanced Progressive Matrices (Raven et al., 1998) is a nonverbal type of test that measures fluid intelligence. It consists of 48 multichoice questions, listed in order of difficulty.

Wisconsin Card Sorting Test (Heaton et al., 1993) assesses the possibility of creating and changing the principles of categorization, using the task of classifying a series of cards according to one of the three classification criteria (color, form and number of elements).

Trail Making Test - Form A and B (Reitan, 1955; Spreen \& Strauss, 1998). This test consists of two parts, each with a specific aim. The first part aims to measure attention, concentration, visual observation, visuospatial estimation and visuomotor abilities, while the second part assesses complex conceptual monitoring, as a type of executive abilities.

Verbal Fluency Test - Phonemic and Category (Goodglass \& Kaplan, 1983; Lezak, 1995). The test consists of three tasks of phonemic and one task of categorical fluency. Verbal fluency is measured by the number of words produced in the unit of time. Words are usually limited to certain categories. Phonemic fluency is assessed by a test of controlled oral associations, including phonemes $\mathrm{S} / \mathrm{K} / \mathrm{L}$ in language equivalent to the Verbal Fluency 
Test (FAS) in the English language. In the Category fluency test, the respondents were asked to generate exemplars from a given category. In this study, the respondents were asked to indicate, within a minute, as many different animals as possible.

Participants completed two computer-based tasks of executive functions designed for this research. The first computer-based task (Go/No-Go task) was used to assess the ability of Inhibition. The second computer-based task was used to assess Mental Shifting/Flexibility abilities. The computer-based tasks are supported in PsychoPy 1.74 for Windows software, which is in the public domain.

\section{Environment Measures}

Block Environmental Questionnaire (German version; Riemann \& Wagner, 2000) derived from the American version (Hur \& Bouchard, 1995) is a 5-point Likert-type questionnaire intended to assess retrospective perceptions of family environment in twin families. It consists of six scales: Acceptance/Rejection by Mother, Acceptance/Rejection by Father, Family Cohesion, Intellectual Orientation of Mother, Intellectual Orientation of Father and Family Organization.

Adult Sibling Relationship Questionnaire (Stocker et al., 1995) assesses characteristics of the relationship between twins by self-reported behaviors and feelings toward siblings, as well as perceptions of siblings' behavior and feelings toward them. The questionnaire includes 81 items conceptually grouped into 14 scales: Intimacy, Affection, Knowledge, Acceptance, Similarity, Admiration, Emotional Support, Instrumental Support, Dominance, Competition, Antagonism, Quarrelling, Maternal Rivalry and Paternal Rivalry.

Life Events List (Plomin et al., 1990; Saudino et al., 1997) consists of 31 life events, while response categories are (1) never, (2) one-time and (3) repeatedly experienced within the last 5 years. In addition, twins rated the valence of the experiences on a scale ranging from very negative $(-3)$ to very positive $(+3)$.

\section{Mental Health Measures}

Psychiatric Diagnostic Screening Questionnaire (PDSQ; Zimmerman, 2002) consists of 123 items, assessing Axis I psychopathology. The PDSQ is a screening instrument for Major Depressive Disorder, PTSD, Bulimia/Binge-Eating Disorder, Obsessive-Compulsive Disorder, Panic Disorder, Psychosis, Agoraphobia, Social Phobia, Alcohol Abuse/Dependence, Drug Abuse/Dependence, Generalized Anxiety Disorder, Somatization Disorder, and Hypochondriasis.

Satisfaction with Life Scale (SWLS; Diener et al., 1985) consists of five items with a 5-point Likert scale and assesses the cognitive component of subjective well-being.

\section{General Medical Examination}

A general medical examination included a general physical and neurological exam, as well as the measurement of the body height, weight and subsequent anthropometric measurements (skinfolds: chest, subscapular, midaxillary, biceps, triceps, abdominal, suprailiac, supraspinal, thigh and calf; circumference: head, neck, forearm, upper arm relaxed and flexed, chest, waist, hip, quadriceps and calf; diameter: femur, humerus, forearm, forearm and hand, and thigh). Body height and weight were used to obtain the body mass index (BMI).
A general physical exam consisted of personal medical history since birth, childhood and adolescence; family history regarding twin pregnancies and the history of neurological disorders and physical illnesses; and a structured physical exam with an evaluation of the heart rate, blood pressure and respiratory rate. The neurological exam evaluated the status of cranial nerves, pyramidal, extrapyramidal, cerebellar, sensory and peripheral nerves, as well as the walking and speaking ability.

\section{Data Collection and Procedures}

Data collection is mostly done at the Faculty of Philosophy in Novi Sad, while a small part of the sample was collected in other Serbian cities: Belgrade, Niš, Zrenjanin and Novi Pazar. The session lasts from 3 to $5 \mathrm{~h}$, with a break for a meal and refreshments. The examination itself is conducted in several stages:

(1) The twin-pair undergoes a general medical examination.

(2) Buccal swabs are taken from the twin-pair for DNA analysis.

(3) The twin-pair participates in a comprehensive interview, in which both twins provide basic information about their similarities and differences, preexisting illnesses, schooling and family opportunities while growing up.

(4) The twin-pair completes personality and intellectual assessment tests. Participants performed executive function tests individually with trained researchers.

(5) The twin-pair participates in computer-based testing of executive functions.

(6) The twin-pair participates in computer-based testing of laboratory-induced aggression.

After the examination process, every twin-pair receives information about the test results by email or at their home address in the form of the report on personality structure and cognitive performance.

\section{Molecular Genetic Analysis}

Until now, molecular genetic analyses have been performed for Human Catechol-O-methylTransferase (COMT), dopamine D2 receptor (DRD2) and Human Brain-Derived Neurotrophic Factor $(B D N F)$ genes, while all necessary preparations have been made for the tryptophan hydroxylase 2 (TPH2) and Gene 5-hydroxytryptamine receptor 1A (HTR1A) genes.

The COMT gene, located at position 22q11, consists of six exons, of which the first two are noncoding. One of the most studied polymorphisms is Val158Met (rs4680) in the fourth exon, which is involved in biosynthesis and metabolism of dopamine, norepinephrine and epinephrine (Salunkhea et al., 2019).

The DRD2 gene is located at the 11q22.3-11q23.1 position, consisting of eight exons, codes for a G-protein-bound receptor, expressed predominantly in the hippocampus, which is considered to have a protective effect on memory. One of the most frequently studied polymorphisms is rs1800497 and SNP rs1800497, which have been associated with many behavioral phenotypes (Klaus et al., 2019).

The BDNF gene is located on chromosome $11 \mathrm{p} 13$ and consists of 11 exons (Pruunsild et al., 2007). One of its most frequent single nucleotide polymorphisms is rs6265 at position 196 of exon 2, which results in valine (val) to methionine (met) substitution at codon 66 (Val66Met). The consequences of this polymorphism involve alterations of $B D N F$ intracellular packaging, its axonal 
transport and activity-dependent secretion at the synapse (Chen et al., 2004).

The TPH2 gene, located at chromosome 12q21.1, encodes a member of the pterin-dependent aromatic acid hydroxylase family. The encoded protein catalyzes the first and rate-limiting step in the biosynthesis of serotonin, an important hormone and neurotransmitter. One of the TPH2 gene's frequent polymorphisms is rs4570625, also known as G-703T, which has been linked to several psychiatric and/or behavioral phenomena (Gao et al., 2012).

The HTR1A gene, which encodes a G-protein-coupled receptor for 5-hydroxytryptamine (serotonin), is located at chromosome $5 \mathrm{q} 12.3$. One of the most investigated polymorphisms of this gene is rs6295, which leads to the replacement of C with G (Drago et al., 2007).

DNA was extracted using standard DNA extraction techniques (QIAgen, Hilden, Germany) as recommended by the manufacturer. The genotyping of the DRD2 gene (rs1800497), COMT gene (rs4680) and BDNF gene (rs6265) was carried out using TaqMan assays (TaqMan single nucleotide polymorphism (SNP), Applied Biosystems, Warrington, UK), as recommended by the manufacturer at the Faculty of Medicine, University of Novi Sad, Serbia. The TaqMan SNP genotyping assays uses TaqMan 5' nuclease chemistry for amplifying and detecting specific polymorphisms in purified genomic DNA samples and takes advantage of minor groove-binding probes for superior allelic discrimination. The SNP genotyping assays contain a VIC-dye-labeled probe and FAM-dyelabeled probe with two target-specific primers. PCR is performed using $10 \mathrm{ng}$ of genomic DNA together with $1 \mu \mathrm{l}$ TaqMan genotyping assay and $12.5 \mu \mathrm{l}$ of genotyping master mix in a final $25 \mu \mathrm{l}$ reaction on a 96-well plate using ABI Prism 7500 Fast PCR device (Applied Biosystems, Foster City, California, USA). DRD2, $C O M T$ and $B D N F$ alleles with the specific fluorescence curves were detected and analyzed using the 7500 System SDS program, integrated into the ABI Prism 7500 Fast PCR device. The genotyping of the TPH2 and HTR1A will begin by the end of 2019 .

\section{Collaborations}

Our research team collaborates with Professor Rainer Riemann from the University of Bielefeld, who helped design the study at its beginning. A great help in determining zygosity via DNA analysis has been provided by Mechthild Prinz from John Jay College of Criminal Justice, City University of New York and Zoran Budimlija from the Department of Neurology, NYU School of Medicine, New York.

Preliminary results of the first behavioral genetic study in Serbia have been published in the special issue of Primenjena Psihologija, dedicated to behavioral genetics (Dinić et al., 2019; Jovanov \& Zgonjanin Bosić, 2019; Milovanović et al., 2019; Nikolašević et al., 2014; Sadiković et al., 2019). Primenjena Psihologija (Applied $P$ sychology) is an open access journal of high importance in Serbia.

\section{Future Plans}

Our future activities are organized in three directions. First, we intend to conduct further data collection from already tested participants in order to examine the relationship between epigenetic change and the development of different psychological phenomena across the life span. Second, we are preparing the assessment of the young twins from the earliest period of their childhood through the end of adolescence, and further. In our register, there are 327 pairs of young twins (101 pairs aged $0-5$;
163 pairs aged 6-10; 42 pairs aged 11-14; and 21 pairs aged 15-17) whose parents had applied to participate in our study. Our medical team has organized the systematic examination of psychomotor and socioemotional development of the youngest twins through standard medical procedures (medical history, measurement of weight, height, BMI, comparison with the World Health Organization (WHO) Growth Standards for children and complete physical examination; WHO, 2016), but also using the parent reports by Ages and Stages Questionnaires (Squires \& Bricker, 2009; Squires et al, 2015). Our medical team has also organized the systematic examination of the school twin cohort through the same medical procedures mentioned above and comparison with the World Health Organization Growth Reference Data for 5-19 years (WHO, 2013). The school twin cohort will be examined partly through parent reports on our online platform, and partly by individual testing, depending on the twins' age. Parents will respond to a set of questionnaires that are primarily intended to evaluate personality (Kodžopeljić et al., 2019) and executive functions (Thorell \& Nyberg, 2008) in children. Individual testing will include assessment of intelligence using the Wechsler Intelligence Scale for Children form IV (WISC-IV) (Wechsler, 2003, adapted by Matešić, 2009), emotional regulation using the ERQ - Child Version (Gullone \& Taffe, 2012) and satisfaction with life using the SWLS - Child Version (Gadermann et al., 2009), and also assessment of some new constructs in children twin studies, such as math anxiety ( Hart et al., 2016). We are also planning to collect information about parents and siblings through time in order to conduct longitudinal research and a nuclear family twin study. The third direction of our plans is aimed to investigate the molecular genetic basis of different psychological phenomena in children and adults, mapping the genetic factors that are related to serotonin- and dopamine-induced behaviors or psychological traits. Overall, our intention in the future is to provide an extensive dataset that could be used for improving not only the knowledge about the behavioral genetic foundations of human characteristics but also quality of life, using the biopsychosocial twin research framework.

\section{Open Science and Science Communication}

Relying on the attitude that 'the field is imbued with an ethos of building a progressive science based on replicable findings' (Plomin et al., 2016, p. 17), our research team is dedicated to replicating previous findings in behavioral genetics and respecting the basic principles of open science.

Data regarding CRTT task, zygosity, polymorphisms, AQ and RST as well as CRTT procedure in PsychoPy software can be found at OSF: https://osf.io/j4vqx/. Data regarding behavioral genetic study of NEO-FFI personality traits in German, Croatian and Serbian culture can be found at OSF: https://osf.io/5shdy/

In order to popularize STR, raise awareness about the importance of twin studies and engage community members in research, STR and CBG activities are continuously being promoted through various public campaigns, events, lectures and TV appearances. One of the key events of this kind is the National Twins Day, organized annually by the CBG team at the University of Novi Sad in the first week of June. The event features assorted activities, such as presenting research results, organizing workshops for parents and children, art performances, prize games, as well as recruiting new participants. Twins who had participated in the research receives the results of their personality profiles, cognitive abilities, general health and zygosity. National Twins Day gathers 
not only twins and their families, but also the members of the academic and public community. Another relevant science communication event is the annual National Science Festival where the CBG team presents their current research and popularize STR through various popular science projects, such as the 'Who is your movie hero twin?' online questionnaire.

Acknowledgments. The authors would like to thank Rainer Riemann for his great help in all stages of our study, Dragana Zgonjanin and Mechthild Prinz for their great help in determining DNA zygosity and Petar Čolović for his great help in creating scripts for quantitative molecular genetic analysis in R environment (Čolović, 2019). We are grateful for the great contribution of alumni: Biljana Vulović, Filip Nenadić, Milan Jordanov, Dina Bojić, Tomislav Ludajić, Sara Raković, Tamara Otašević, Miljana Marić Ognjenović, Katarina Ostojić, Ana Stanković, Tijana Brzić, Tea Teofanovska, Vojana Obradović, Anđela Cvetićanin, Dragana Nedeljković, Jelena Milošević, Jelena Mitrović, Slobodan Golušin, Dragan Đunda, Mina Velimirović, Marija Bulat, Luka Todorović, Damir Bogdan, Tamara Stanojković and psychology students: Milana Jovanov, Ivona Jerković, Luna Radević, Marko Milošević and Nataša Katić.

Financial support. This research was supported by the Ministry of Education, Science and Technological Development of the Republic of Serbia (\#179006).

\section{References}

Buss, A. H., \& Perry, M. (1992). The aggression questionnaire. Journal of Personality and Social Psychology, 63, 452-459.

Chen, Z.-Y., Patel, P. D., Sant, G., Meng, C. X., Teng, K. K., Hempstead, B. L., \& Lee, F. S. (2004). Variant brain-derived neurotrophic factor (BDNF) (Met66) alters the intracellular trafficking and activity-dependent secretion of wild-type BDNF in neurosecretory cells and cortical neurons. Journal of Neuroscience, 24, 4401-4411.

Čolović, P. (2019). Petarcolovic/R_CqBG 1.0.0-Beta. Zenodo open data repository.

Čolović, P., Branovački, B., \& Zgonjanin Bosić, D. (2019). Validation of zygosity assessment by a self-report questionnaire in a sample of adult Serbian twins. Primenjena Psihologija, 11, 419-432.

Costa, P. T. Jr., \& McCrae, R. R. (1992). Revised NEO Personality Inventory (NEO-PI-R) and NEO Five-Factor Inventory (NEO-FFI) professional manual. Odessa, FL: Psychological Assessment Resources.

Costa, P. T. Jr., \& McCrae, R. R. (2019). Srpska standardizacija NEO petofaktorskog inventara NEO-FFI: forma $S$ [The Serbian standardization of the NEO Five-Factor Inventory NEO-FFI: Form S]. Beograd: Sinapsa Edicije.

Diener, E. D., Emmons, R. A., Larsen, R. J., \& Griffin, S. (1985). The satisfaction with life scale. Journal of Personality Assessment, 49, 71-75.

Dinić, B., \& Janičić, B. (2012). Evaluation of Buss-Perry aggression questionnaire with item response theory (IRT). Psihologija, 45, 189-207.

Dinić, B., Nikolašević, Ž., Oljača, M., \& Bugarski Ignjatović, V. (2019). Twin study of aggressiveness and impulsiveness relationship. Primenjena Psihologija, 11, 451-470.

Drago, A., Ronchi, D. D., \& Serretti, A. (2007). 5-HT1A gene variants and psychiatric disorders: A review of current literature and selection of SNPs for future studies. The International Journal of Neuropsychopharmacology, $11,701-721$.

Gadermann, A. M., Schonert-Reichl, K. A., \& Zumbo, B. D. (2009). Investigating validity evidence of the satisfaction with life scale adapted for children. Social Indicators Research, 96, 229-247.

Gao J., Pan Z., Jiao Z., Li F., Zhao G., Wei Q., Pan F., \& Evangelou E. (2012) TPH2 gene polymorphisms and major depression - A meta-analysis. PLoS ONE, 7, e36721.

Goodglass, H., \& Kaplan, E. (1983). The assessment of aphasia and related disorders. Philadelphia, PA: Lea \& Febiger.

Gray, J. A., \& McNaughton, N. (2000). The neuropsychology of anxiety: An enquiry into the functions of the septo-hippocampal system (2nd ed.). Oxford, UK: Oxford University Press.
Gullone, E., \& Taffe, J. (2012). The Emotion Regulation Questionnaire for Children and Adolescents (ERQ-CA): A psychometric evaluation. Psychological Assessment, 24, 409-417.

Hart, S. A., Logan, J. A. R., Thompson, L., Kovas, Y., McLoughlin, G., \& Petrill, S. A. (2016). A latent profile analysis of math achievement, numerosity, and math anxiety in twins. Journal of Educational Psychology, 108, 181-193.

Heaton, R. K., Chelune, G. J., Talley, J. L., Kay, G. G., \& Curtiss, G. (1993). Wisconsin card sorting test manual: Revised and expanded. Odessa, FL: Psychological Assessment Resources.

Hur, Y.-M., \& Bouchard, T. J. (1995). Genetic influences on perceptions of childhood family environment: A reared apart twin study. Child Development, $66,330-345$.

Jovanov, M., \& Zgonjanin Bosić, D. (2019). Sensation seeking and risky behaviors in light of genetic and environmental factors. Primenjena Psihologija, 11, 471-486.

Klaus, K., Butler, K., Curtis, F., Bridle, C., \& Pennington, K. (2019). The effect of ANKK1 Taq1A and DRD2 C957T polymorphisms on executive function: A systematic review and meta-analysis. Neuroscience \& Biobehavioral Reviews, 100, 224-236.

Kodžopeljić, J., Smederevac, S., Mitrović, D., Čolović, P., \& Pajić D. (2019). Velikih pet plus dva za decu - primena i interpretacija [Big Five plus Two for Children - Application and interpretation]. Beograd: Centar za Primenjenu Psihologiju.

Lezak, M. D. (1995). Neuropsychological assessment (3rd ed.). New York, NY: Oxford University Press.

Matešić, K. (2009). Wechlerov test inteligencije za decu - četvrto izdanje - WISC $I V$ [Wechsler Intelligence Scale for Children - Fourth Edition - WISC-IV]. Jasterbarsko: Naklada Slap.

Milovanović, I., Sadiković, S., \& Kodžopeljić, J. (2019). Genetic and environmental factors in emotion regulation and life satisfaction: A twin study. Primenjena Psihologija, 11, 399-417.

Nikolašević, Ž., Bugarski-Ignjatović, V., Milovanović, I., \& Raković, S. (2014). Inteligencija i školsko postignuće u svetlu naslednih i sredinskih činilaca [Intelligence and school achievement in light of genetic and environmental factors]. Primenjena Psihologija, 7, 381-400.

Oniszczenko, W., Angleitner, A., Strelau, J., \& Angert, T. (1993). The Questionnaire of Twins' Physical Resemblance. Unpublished manuscript, University of Warsaw, Poland.

Plomin, R., Defries, J. C., Knopik, V. S., \& Neiderhiser, J. M. (2016). Top 10 replicated findings from behavioral genetics. Perspectives on Psychological Science, 11, 3-23.

Plomin, R., Lichtenstein, P., Pedersen, N. L., Mcclearn, G. E., \& Nesselroade, J. R. (1990). Genetic influence on life events during the last half of the life span. Psychology and Aging, 5, 25-30.

Pruunsild, P., Kazantseva, A., Aid, T., Palm, K., \& Timmusk, T. (2007). Dissecting the human BDNF locus: Bidirectional transcription, complex splicing, and multiple promoters. Genomics, 90, 397-406.

Raven, J., Raven, J. C., \& Court, J. H. (1998). Raven manual: Section 1, general overview. Oxford, UK: Oxford Psychologists Press.

Reed, T., Plassman, B. L., Tanner, C. M., Dick, D. M., Rinehart, S. A., \& Nichols, W. C. (2005). Verification of self-report of zygosity determined via DNA testing in a subset of the NAS-NRC Twin Registry 40 years later. Twin Research and Human Genetics, 8, 362-367.

Reitan, R. M. (1955). The relation of the trail making test to organic brain damage. Journal of Consulting Psychology, 19, 393-394.

Riemann, R., \& Wagner, R. (2000). Deutsche Version des Block Environmental Questionnaire nach Hur \& Bouchard (German version of BEQ). Unpublished questionnaire.

Sadiković, S., Smederevac, S., Mitrović, D., \& Milovanović, I. (2019). Behavioral genetics foundations of relations between personality traits and satisfaction with life. Primenjena Psihologija, 11, 487-502.

Salunkhea, G., Feigeb, B., Savillec, C. W. N., Lancasterd, T. M., Stefanoua, M. E., Bendere, S., ... Klein, C. (2019). The impact of the COMT genotype and cognitive demands on facets of intrasubject variability. Brain and Cognition, 132, 72-79.

Saudino, K. J., Pedersen, N. L., Lichtenstein, P., McClearn, G. E., \& Plomin, R. (1997). Can personality explain genetic influences on life events? Journal of Personality and Social Psychology, 72, 196-206. 
Smederevac, S., Mitrović, D., Čolović, P., \& Nikolašević, Ž. (2014). Validation of the measure of revised reinforcement sensitivity theory constructs. Journal of Individual Differences, 35, 12-21.

Spreen, O., \& Strauss, E. (1998). A compendium of neuropsychological tests: Administration, norms, and commentary. New York, NY: Oxford University Press.

Squires, J., \& Bricker, D. (2009). Ages \& stages questionnaires ${ }^{\circledR}$ : A parentcompleted child monitoring system (3rd ed.). Baltimore, MD: Paul H. Brookes Publishing Co.

Squires, J., Bricker, D., \& Twombly, E. (2015). Ages \& stages questionnaires ${ }^{\oplus}$ : Social-emotional: A parent-completed child monitoring system for socialemotional behaviors (2nd ed.). Baltimore, MD: Paul H. Brookes Publishing.

Stocker, C., Lanthier, R., \& Furman, W. (1995) The adult sibling relationship questionnaire. Denver, CO: University of Denver.

Taylor, S. (1967). Aggressive behavior and physiological arousal as a function of provocation and the tendency to inhibit aggression. Journal of Personality, $35,297-310$.
Thorell, L. B., \& Nyberg, L. (2008). The Childhood Executive Functioning Inventory (CHEXI): A new rating instrument for parents and teachers, Developmental Neuropsychology, 33, 526-552.

Warburton, W. A., \& Bushman, B. J. (2019). The competitive reaction time task: The development and scientific utility of a flexible laboratory aggression paradigm. Aggressive Behavior, 45, 389-396.

Wechsler, D. (2003). Wechsler Intelligence Scale for Children, fourth edition (WISC-IV). San Antonio, TX: The Psychological Corporation.

World Health Organisation (WHO). (2013). Growth reference data for 5-19 years. Retrieved from https://www.who.int/growthref/en/

World Health Organization (WHO). (2016). The WHO child growth standards. Retrieved from https://www.who.int/childgrowth/standards/en

Zimmerman, M. (2002). The psychiatric diagnostic screening questionnaire manual. Los Angeles, CA: Western Psychological Services.

Zuckerman, M. (1994). Behavioral expressions and biological bases of sensation seeking. New York, NY: Cambridge University Press. 